\title{
Retained cilia in anterior chamber in repaired post- traumatic corneal laceration
}

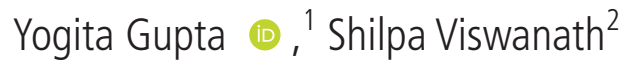

${ }^{1}$ Ophthalmology, All India Institute of Medical Sciences, New Delhi, India

${ }^{2}$ Department of Ophthalmology (RP Centre), All India Institute of Medical Sciences, New Delhi, India

\section{Correspondence to} Dr Yogita Gupta; yogitagupta30@gmail.com

Accepted 21 January 2021
Check for updates

(C) BMJ Publishing Group Limited 2021. No commercial re-use. See rights and permissions. Published by BMJ.

\begin{tabular}{l}
\hline To cite: Gupta Y, \\
Viswanath S. BMJ Case \\
Rep 2021;14:e241447. \\
doi:10.1136/bcr-2020- \\
241447 \\
\hline
\end{tabular}

\section{DESCRIPTION}

A 20-year-old male patient presented to our tertiary eye centre with post-traumatic cataract in the right eye, 3 months after penetrating trauma with metal wire while working with electric cables. The corneal laceration had been repaired soon after trauma elsewhere and the patient had some gain of vision post-surgery, following which the vision further deteriorated. On examination, there was a healed vertical corneal laceration, $7 \mathrm{~mm}$ in length, in the temporal part of the cornea with partially absorbed traumatic cataract, obscuring the visual axis and a temporal iridodialysis ( 5 clock hours extent). To our surprise, there was a cilium in the anterior chamber (AC) superiorly, with an end attached to the iris (figure 1). There was no associated active inflammation or AC reaction. The timing of dislodgement of cilia in the AC might be during the initial event of trauma or while the patient underwent primary repair of laceration (while doing sterile surgical draping, or while repositing the apparently viable uveal tissue inside the eye). We hypothesised that in our case, the cilium was probably missed during the primary repair of the corneal tear. The similar colour of the cilia and the iris tissue could be a possible explanation for this. The patient subsequently underwent lens aspiration with removal of the cilia in the AC. The postoperative period was uneventful and the patient achieved a best-corrected visual acuity of 20/30 at sixth postoperative week.

Possible mechanism of dislodgement of cilia was explained by Duke-Elder ${ }^{1}$ as follows. Fast-moving

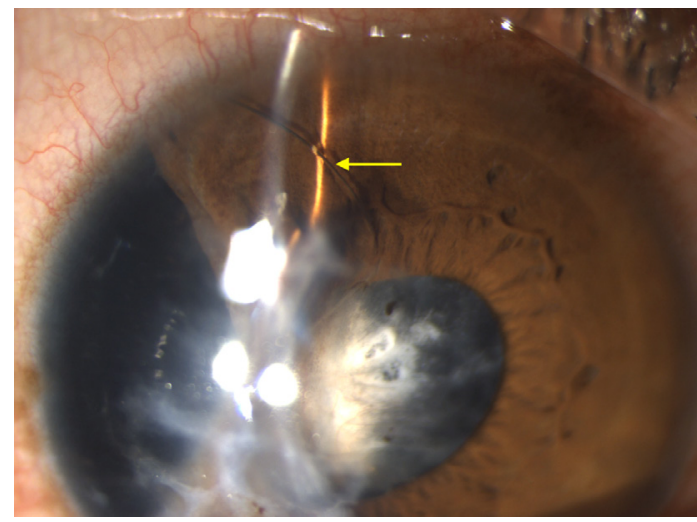

Figure 1 Clinical photograph (slit lamp biomicroscope image) of the right eye showing a retained cilia in the anterior chamber (yellow arrow) appreciated clearly in thin slit illumination, seen with post-traumatic repaired corneal laceration, post-traumatic cataract obscuring the visual axis and temporal iridodialysis. The colour of the cilia was noted to be similar to that of the iris tissue.

\section{Learning points}

- Cilia may be accidentally implanted intraocularly during ocular trauma or during primary repair of corneal wound.

- Careful slit lamp examination and examination under anaesthesia in operating room, just prior to the primary repair of corneal tear and also after completion of the repair, helps to avoid retaining of foreign bodies inside the eye.

- Intraoperative anterior chamber irrigation and abscission of devitalised uveal tissue helps prevent contamination.

objects (eg, metal chips) result in reflexive closure of the eyelids only after the foreign body has contacted the conjunctiva or cornea, thus not giving ample amount of time for eyelashes to enter into the path of the foreign body. In contrast, eyelids reflexively close before a slow-moving object (eg, a wire) comes in contact with the ocular surface, and this allows them to enter the path of the foreign body. Our case also involved penetrating ocular trauma caused by a metal wire, which often is the cause of injury in majority of patients with intraocular cilia. Gopal et $a l^{2}$ conducted a case series of intraocular cilia post penetrating ocular trauma in which he stated that metallic wire was responsible for the injury in 6 of 11 eyes with intraocular cilia.

Limited trauma cases have been reported about cilia in the AC. Alami et $a l^{3}$ reported a similar case of post-traumatic cilia in the AC, where observation was done for the inert cilia. Yalniz-Akkaya ${ }^{4}$ demonstrated a cilium remaining inert for 50 years in the AC without causing any reaction in the AC. Posttraumatic intraocular cilia comprise nearly $0.4 \%$ of all intraocular foreign bodies. ${ }^{3}$

There are a few reports of posterior segment cilia in the literature. Ramos et $a l^{5}$ documented an extremely rare case of nine intraocular cilia embedded in the retina after a perforating ocular injury caused by a metal wire. Gupta et $a l^{6}$ documented similar case of two cilia embedded in the retina post penetrating ocular trauma. In both the cases, the cilia were removed through pars plana vitrectomy.

Contributors Both YG and SV contributed to the manuscript. YG contributed to the concept, design of the work, acquired data, and revised and reviewed the manuscript. SV interpreted the data of the work, drafted the manuscript and revised the manuscript.

Funding The authors have not declared a specific grant for this research from any funding agency in the public, commercial or not-for-profit sectors. 
Competing interests None declared.

Patient consent for publication Obtained.

Provenance and peer review Not commissioned; externally peer reviewed.

\section{ORCID iD}

Yogita Gupta http://orcid.org/0000-0002-2479-797X

\section{REFERENCES}

1 pp. S. Duke elder system of ophthalmology cv Mosby CO. St. Louis, MO 1972:553-61.
2 Gopal L, Banker AS, Sharma T, et al. Intraocular cilia associated with perforating injury. Indian J Ophthalmol 2000;48:33-6.

3 Alami F, Chokrani H, Bengraii W, et al. Post-Traumatic cilia in the anterior chamber. J Fr Ophtalmol 2015;38:373-4.

4 Yalniz-Akkaya Z. Post-Traumatic cilia remaining inert in the anterior chamber for 50 years: a case report. J Med Case Rep 2011;5:527.

5 Ramos GZ, Goncalves TB, Bordon AF. An unusual case of nine cilia embedded in the retina after a perforating ocular injury. Am J Ophthalmol Case Rep 2020;17:100587.

6 Gupta AK, Ghosh B, Mazumdar S, et al. An unusual intraocular foreign body. Acta Ophthalmol Scand 1996;74:200-1.

Copyright 2021 BMJ Publishing Group. All rights reserved. For permission to reuse any of this content visit

https://www.bmj.com/company/products-services/rights-and-licensing/permissions/

BMJ Case Report Fellows may re-use this article for personal use and teaching without any further permission.

Become a Fellow of BMJ Case Reports today and you can:

- Submit as many cases as you like

- Enjoy fast sympathetic peer review and rapid publication of accepted articles

- Access all the published articles

Re-use any of the published material for personal use and teaching without further permission

\section{Customer Service}

If you have any further queries about your subscription, please contact our customer services team on +44 (0) 2071111105 or via email at support@bmj.com.

Visit casereports.bmj.com for more articles like this and to become a Fellow 